PAPER

A comprehensive device modelling of perovskite solar cell with inorganic copper iodide as hole transport material

To cite this article: Syed Zulqarnain Haider et al 2018 Semicond. Sci. Technol. 33035001

View the article online for updates and enhancements. 


\title{
A comprehensive device modelling of perovskite solar cell with inorganic copper iodide as hole transport material
}

\author{
Syed Zulqarnain Haider ${ }^{1}$, Hafeez Anwar ${ }^{1}\left(\mathbb{B}\right.$ and Mingqing Wang ${ }^{2}$ \\ ${ }^{1}$ Department of Physics, University of Agriculture Faisalabad, 38040, Pakistan \\ ${ }^{2}$ Institute for Materials Discovery, University College of London, United Kingdom \\ E-mail: hafeez.anwar@gmail.com
}

Received 16 September 2017, revised 11 December 2017

Accepted for publication 5 January 2018

Published 25 January 2018

\begin{abstract}
Hole transport material (HTM) plays an important role in the efficiency and stability of perovskite solar cells (PSCs). Spiro-MeOTAD, the commonly used HTM, is costly and can be easily degraded by heat and moisture, thus offering hindrance to commercialize PSCs. There is dire need to find an alternate inorganic and stable HTM to exploit PSCs with their maximum capability. In this paper, a comprehensive device simulation is used to study various possible parameters that can influence the performance of perovskite solar cell with CuI as HTM. These include the effect of doping density, defect density and thickness of absorber layer, along with the influence of diffusion length of carriers as well as electron affinity of electron transport layer (ETM) and HTM on the performance of PSCs. In addition, hole mobility and doping density of HTM is also investigated. $\mathrm{CuI}$ is a p-type inorganic material with low cost and relatively high stability. It is found that concentration of dopant in absorber layer and HTM, the electron affinity of HTM and ETM affect the performance of solar cell minutely, while cell performance improves greatly with the reduction of defect density. Upon optimization of parameters, power conversion efficiency for this device is found to be $21.32 \%$. The result shows that lead-based PSC with CuI as HTM is an efficient system. Enhancing the stability and reduction of defect density are critical factors for future research. These factors can be improved by better fabrication process and proper encapsulation of solar cell.
\end{abstract}

Keywords: perovskite solar cells, inorganic HTM, device simulation, defect density, copper iodide

(Some figures may appear in colour only in the online journal)

\section{Introduction}

Lead-based perovskite solar cells (PSCs) have achieved remarkable repute due to their simpler fabrication techniques and lower cost as compared to traditional silicon solar cells [1]. For the last few years, power conversion efficiency (PCE) of lead-based PSCs has been significantly improved from $3.8 \%$ in 2009 to $22 \%$ in 2016 [2]. However, these power conversion efficiencies are still low as compared to inorganic solar cells such as copper indium gallium diselenide (CIGS, $22.6 \%$ ), crystalline silicon (c-Si, 25.7\%), gallium arsenide (GaAs, 28.8\%) and cadmium telluride (CdTe, 22.1\%). Methyl ammonium lead iodide $\left(\mathrm{CH}_{3} \mathrm{NH}_{3} \mathrm{PbI}_{3}\right)$ with a band gap of $1.50 \mathrm{eV}$ that covers absorption within wide range of visible spectrum was reported by various experimental and theoretical studies [3]. Generally, PSCs consist of hole transporting layer, electron transporting layer and absorber layer. The role of each layer in PSCs should be understood in order to improve the device performance [4].

The commonly used hole transport material (HTM) is organic in nature and is known as spiro-MeOTAD [5]. There are two typical additives, 4-tert-butylpyridine (TBP) and bis(trifluoromethane) sulfonamide lithium salt (Li-TFSI), are used to improve the conductivity and hole mobility 
of spiro-MeOTAD. While promoting polarity in spiroMeOTAD, unfortunately, TBP dissolves the absorber material [6]. At the same time, Li-TFSI promotes the oxidation process in spiro-MeOTAD which again destroys the absorber layer $[7,8]$. In addition to these drawbacks, spiro-MeOTAD is very expensive (even more expensive than absorber material) due to its multistep synthetic approach and time consuming purification process [9]. Spiro-MeoTAD based PSCs has achieved PCE from 6\% [10] to almost $20 \%$ [11], but retained only $20 \%$ of the initial PCE after 10 days due to its sensitivity to moisture and oxygen [12]. Besides spiro-MeOTAD, other commonly used organic HTMs in PSCs include PEDOT: PSS, P3HT and PTAA. PEDOT: PSS based PSCs has achieved PCE from $3.9 \%$ [13] to $18.1 \%$ [14], but retained only $27 \%$ of its initial PCE after 14 days [15]. PEDOT: PSS suffers poor chemical stability, owing to that its hygroscopic nature lacks the ability to block electrons, thus requiring extra layer for efficient performance. In addition, PEDOT: PSS corrodes the substrates due to its acidic nature [16]. P3HT based PSCs has achieved PCE from $6.45 \%$ [17] to $15.3 \%$ in composite form with single walled carbon nanotubes and degraded $5 \%$ in $60 \mathrm{~s}$ under thermal stressing [18]. Furthermore, in order to avoid direct contact of P3HT with back metal contact, a blocking layer which is unable to transport charges such as poly methyl methacrylate (PMMA) was used [19]. PTAA based PSCs has achieved the PCE from 12\% [20] to 20.2\% [21] and degraded only $5 \%$ in 20 days, showing the better performance than PEDOT: PSS [22]. Organic HTMs guaranteeing high PCE of PSCs, but the necessity of external doping make them more prone to degradation over time under humidity. Furthermore, manufacturing cost plays an important role in commercializing PSC, while most of organic HTMs are too expensive. High efficiency, long term stability, and low-cost are the main factors plays decisive role in the success of a photovoltaic technology $[23,24]$. Therefore, it is dire need to replace costly and unstable HTMs with a cost effective and stable HTM having high hole mobility with ease of synthesis. Inorganic p-type semi-conductor such as copper iodide is considered to be an alternative of organic HTMs [25]. Moreover, CuI based PSCs retained $90 \%$ of its initial PCE after 14 days storage in air [15] and retained $92 \%$ of its initial PCE after 90 days storage in dark [26]. Table 1 shows the cost, PCE and $V_{\text {oc }}$ of various organic HTMs compared with CuI. It is obviously shown in table 1 that $\mathrm{CuI}$ is a very low cost candidate HTM for efficient perovskite solar cell. CuI exhibited electrical conductivity two orders of magnitude higher than spiro-MeOTAD that allowed appreciably higher fill factor (FF) as determined by impedance spectroscopy [27]. In addition to high conductivity, low cost, hydrophobic nature, excellent ambient stability, wide band gap and solution processability make $\mathrm{CuI}$ a very promising HTM material.

Further, $\mathrm{CuI}$ thin films show high transmittance in the range of 450-800 $\mathrm{nm}[28,29]$ than PEDOT: PSS, making it potential material for HTM, as this transmittance range is considered to be suitable to get good absorbance in absorber layer of PSCs [13]. Due to its good transparent nature, more photon flux can reach to absorber layer and more photocurrent could be generated. Above all, due to its inorganic nature, $\mathrm{CuI}$ exhibits relatively high air stability, making it a very promising candidate for PSCs with long term stability [30]. Initially, PSCs achieved PCE of 6\% with CuI as HTM [31]. Recently, PCE has been greatly improved and reached up to $17.6 \%$ when $\mathrm{CuI}$ film was prepared by facile spray deposition [26]. Although the efficiency of PSCs improved rapidly from last few years by various researchers, still their efficiencies have not reached to the maximum theoretical Shockley-Queisser limit $(31.4 \%)$ [32, 33]. Except for experiment work, it is also equally important to investigate all aspects of the device theoretically in order to fully understand the device mechanism and optimize the device performance. Solar cell capacitance simulator (SCAPS) is used for the simulation of lead-based and lead-free PSCs by many researchers [34]. In terms of CuI as HTM in leadbased PSCs, very little work has been done so far. For example, perovskite $\left(\mathrm{CH}_{3} \mathrm{NH}_{3} \mathrm{PbI}_{3}\right)$ solar cells with $\mathrm{CuI}$ as HTM was simulated using SCAPS, while only the effect of thickness of the absorber on the performance of PSCs was investigated [35]. In another device modeling, perovskite solar cell was simulated with various HTMs including CuI, while only the effect of thickness and defect density of the absorber layer were investigated [36]. In addition to the thickness of the absorber, there are also many other critical parameters which could affect the performance of PSCs. These include doping concentration in the absorber layer, defect density of the absorber layer taking into account the diffusion length and electron affinity of ETM and HTM. For example, selection of suitable electron affinity of ETM and HTM can prevent interface recombination, thus can help to improve device performance. Therefore, a detailed and thorough investigation of all these parameters needs to be done for further understanding of device mechanism and thus improving device performance.

In this paper, SCAPS is used for the simulation of lead based $\mathrm{CH}_{3} \mathrm{NH}_{3} \mathrm{PbI}_{3}$ PSCs with $\mathrm{CuI}$ as $\mathrm{HTM}$ and $\mathrm{TiO}_{2}$ as ETM. A detailed analysis is presented about the influence of all above mentioned parameters on the performance of PSCs.

\section{Device simulation parameters}

Planar heterojunction structure has been adopted for $\mathrm{CH}_{3} \mathrm{NH}_{3} \mathrm{PbI}_{3}$ based solar cell with layer configuration of glass substrate/TCO (transparent conducting oxide) $/ \mathrm{TiO}_{2}$ (ETM)/absorber layer $\left(\mathrm{CH}_{3} \mathrm{NH}_{3} \mathrm{PbI}_{3}\right) / \mathrm{CuI}(\mathrm{HTM}) /$ metal back contact as shown in figure 1(a).

The band diagram is shown in figure 1(b). It is clear shown that the valence band offset at the $\mathrm{CH}_{3} \mathrm{NH}_{3} \mathrm{PbI}_{3} / \mathrm{CuI}$ interface is $+0.32 \mathrm{eV}$, which is crucial for the flow of holes to the back-metal contact in order to avoid their recombination with the electrons in the absorber layer. The conduction band offset is $+0.36 \mathrm{eV}$ at the $\mathrm{TiO}_{2} / \mathrm{CH}_{3} \mathrm{NH}_{3} \mathrm{PbI}_{3}$ interface, which 

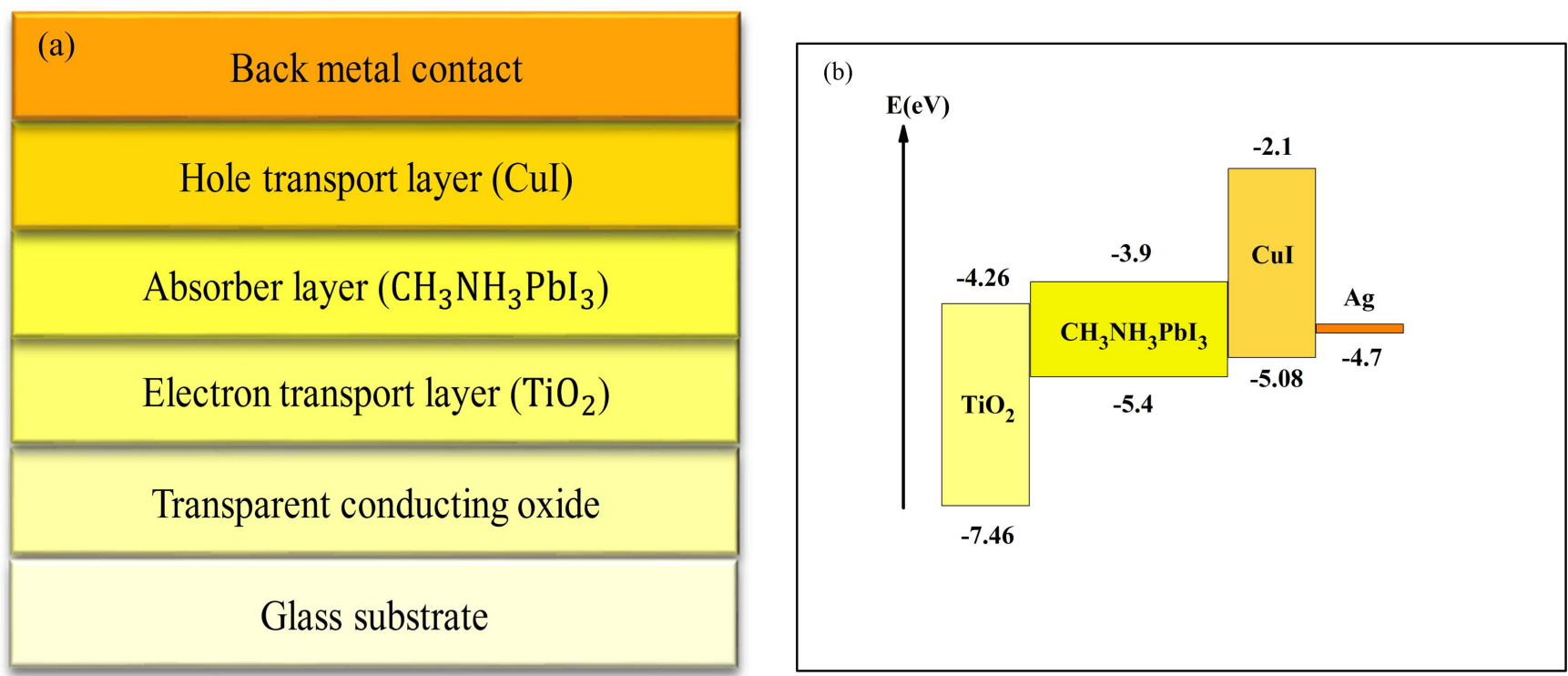

Figure 1. (a) Schematic structure of the device (b) band diagram of the $\mathrm{TiO}_{2} / \mathrm{CH}_{3} \mathrm{NH}_{3} \mathrm{PbI}_{3} / \mathrm{CuI} / \mathrm{Ag}$.

Table 2. Defect parameters of interfaces and absorber.

\begin{tabular}{llll}
\hline Parameters & $\mathrm{CH}_{3} \mathrm{NH}_{3} \mathrm{PbI}_{3}$ & $\mathrm{TiO}_{2} / \mathrm{CH}_{3} \mathrm{NH}_{3} \mathrm{PbI}_{3}$ interface & $\mathrm{CH}_{3} \mathrm{NH}_{3} \mathrm{PbI}_{3} / \mathrm{CuI}$ interface \\
\hline Defect type & Neutral & Neutral & Neutral \\
Capture cross section for electrons $\left(\mathrm{cm}^{2}\right)$ & $2 \times 10^{-15}$ & $2 \times 10^{-16}$ & $2 \times 10^{-14}$ \\
Capture cross section for holes $\left(\mathrm{cm}^{2}\right)$ & $2 \times 10^{-15}$ & $2 \times 10^{-16}$ & $2 \times 10^{-14}$ \\
Energetic distribution & Gaussian & Single & Single \\
Energy level with respect to $E_{\mathrm{v}}(\mathrm{eV})$ & 0.500 & 0.650 & 0.650 \\
Characteristic energy $(\mathrm{eV})$ & 0.1 & 0.1 & 0.1 \\
Total density $\left(\mathrm{cm}^{-3}\right)$ & $1 \times 10^{15}-1 \times 10^{19}$ & $1 \times 10^{18}$ & $1 \times 10^{18}$ \\
\hline
\end{tabular}

Table 3. Simulation parameters of PSCs devices.

\begin{tabular}{lllll}
\hline Parameters & $\mathrm{TCO}$ & $\mathrm{ETM}\left(\mathrm{TiO}_{2}\right)$ & Absorber $\left(\mathrm{CH}_{3} \mathrm{NH}_{3} \mathrm{PbI}_{3}\right)$ & $\mathrm{HTM}(\mathrm{CuI})$ \\
\hline Thickness $(\mu \mathrm{m})$ & 0.500 & 0.030 & 0.350 & 0.100 \\
Band gap energy $E_{\mathrm{g}}(\mathrm{eV})$ & 3.5 & $3.2[39]$ & $1.50[40]$ & $2.98[41]$ \\
Electron affinity $\chi(\mathrm{eV})$ & 4 & $4.26[42]$ & $3.9[43]$ & $2.1[44]$ \\
Relative permittivity $\varepsilon_{\mathrm{r}}$ & 9 & $38-108[45]$ & $10[46]$ & $6.5[47]$ \\
Effective conduction band density $N_{\mathrm{c}}\left(\mathrm{cm}^{-3}\right)$ & $2.0 \times 10^{18}$ & $2.0 \times 10^{18}[48]$ & $2.75 \times 10^{18}[49]$ & $2.8 \times 10^{19}[50]$ \\
Effective valance band density $N_{\mathrm{v}}\left(\mathrm{cm}^{-3}\right)$ & $1.8 \times 10^{19}$ & $1.8 \times 10^{19}$ & $3.9 \times 10^{18}[49]$ & $1.0 \times 10^{19}[50]$ \\
Electron mobility $\mu_{\mathrm{n}}\left(\mathrm{cm}^{2} \mathrm{~V}^{-1} \mathrm{~s}^{-1}\right)$ & 20 & $4[51]$ & $10[52]$ & $1.69 \times 10^{-4}$ \\
Hole mobility $\mu_{\mathrm{p}}\left(\mathrm{cm}^{2} \mathrm{~V}^{-1} \mathrm{~s}^{-1}\right)$ & 8 & $2[51]$ & 10 & $1.69 \times 10^{-4}[53]$ \\
Donor concentration $N_{\mathrm{D}}\left(\mathrm{cm}^{-3}\right)$ & $2.0 \times 10^{19}$ & $1 \times 10^{16}$ & 0 & 0 \\
Acceptor concentration $N_{\mathrm{A}}\left(\mathrm{cm}^{-3}\right)$ & 0 & 0 & $2.1 \times 10^{17}[54]$ & $1 \times 10^{18}[35]$ \\
Defect density $N_{\mathrm{t}}\left(\mathrm{cm}^{-3}\right)$ & $1 \times 10^{15}$ & $1 \times 10^{15}[55]$ & $4.5 \times 10^{17}$ & $1 \times 10^{15}$ \\
\hline
\end{tabular}

is also critical for the flow of photo excited electrons to the front electrode. Neutral Gaussian distribution defect is selected in the absorber layer and characteristic energy is set to be $0.1 \mathrm{eV}$. Two defect interfaces are inserted for carrier recombination. One defect interface is $\mathrm{TiO}_{2} / \mathrm{CH}_{3} \mathrm{NH}_{3} \mathrm{PbI}_{3}$ and the other one is $\mathrm{CH}_{3} \mathrm{NH}_{3} \mathrm{PbI}_{3} / \mathrm{CuI}$. The nature of the defect is set as single and defect density is set as $1 \times 10^{18} \mathrm{~cm}^{-3}$. Table 2 summarizes the defect parameters which are set in the simulation. Absorption coefficient $(\alpha)$ is obtained by tauc plot and $\alpha h \nu=A_{\alpha}\left(h \nu-E_{\mathrm{g}}\right)^{1 / 2}$, which is around $10^{+6} \mathrm{~m}^{-1}$ [37]. Basic parameters for each material used in the simulation are summarized in table 3. Thermal velocities of hole and electron are selected as $10^{7} \mathrm{~cm} \mathrm{~s}^{-1}$ [38]. The optical reflectance is considered to be zero at the surface and at each interface. Parameters are optimized in the study by using control variable method. The initial total 
(a)

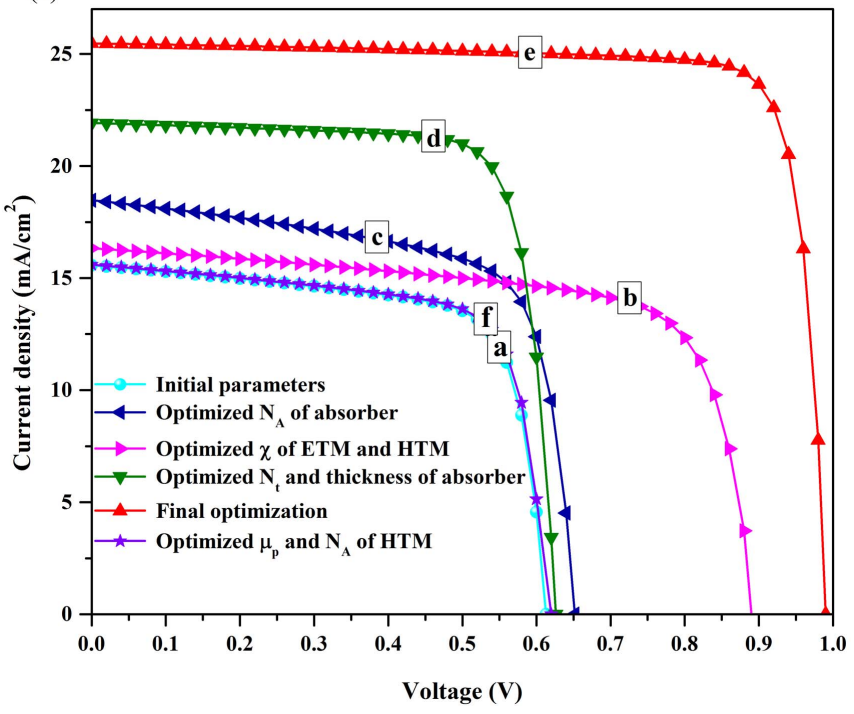

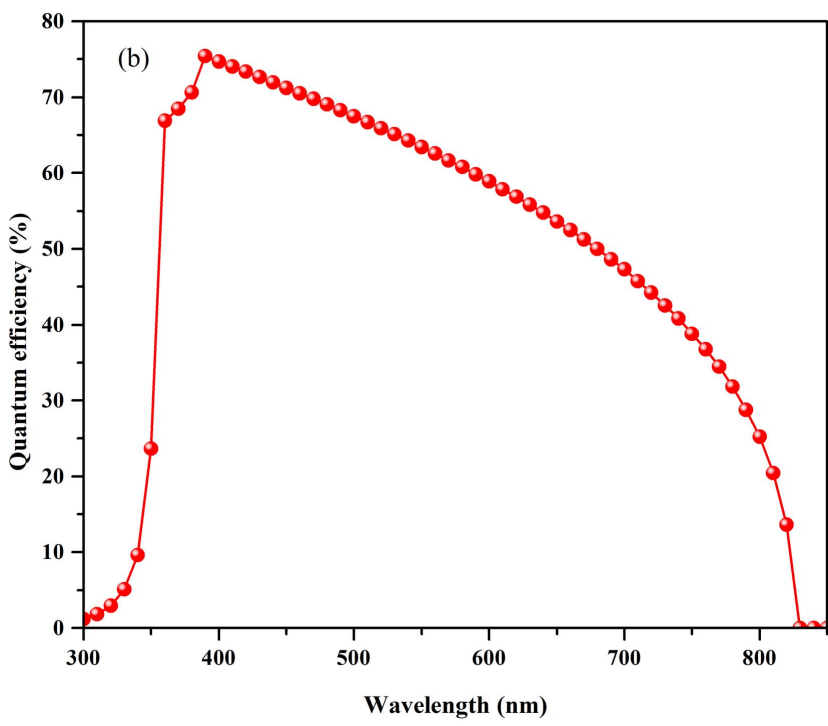

Figure 2. (a) Simulated optimized $J-V$ curves and (b) quantum efficiency curve of PSC with parameters in tables 2 and 3.

defect density of the absorber layer is assumed to be $4.5 \times 10^{17} \mathrm{~cm}^{-3}$.

The current density-voltage curve has been drawn with these initial parameters as shown in curve (a) of figure 2(a).

The short-circuit current density $\left(J_{\mathrm{sc}}\right)$ of $15.57 \mathrm{~mA} \mathrm{~cm}^{-2}$, open-circuit voltage $\left(V_{\mathrm{oc}}\right)$ of $0.61 \mathrm{~V}$, FF of $71.69 \%$, and PCE of $6.85 \%$ are obtained. The simulated device performance is consistent with the experimental results of lead-based PSCs $[56,57]$. This consistency shows that input parameters are valid and close to the real device. In the quantum efficiency (QE) curve in figure 2(b), optical absorption edge is red shifted to $830 \mathrm{~nm}$ which corresponds to a band gap of $1.50 \mathrm{eV}$ in $\mathrm{CH}_{3} \mathrm{NH}_{3} \mathrm{PbI}_{3}$. The $\mathrm{QE}$ covers the whole visible spectrum with maximum absorbance at $400 \mathrm{~nm}$ along with absorption onset to $830 \mathrm{~nm}$, which is closer to the experimental work $[56,57]$.

\section{Results and discussion}

\subsection{Influence of doping concentration $\left(N_{A}\right)$ of absorber layer}

Doping is very significant process in order to enhance the performance of the solar cell. Doping can either be n-type or p-type depending upon the type of dopants. Like the other crystalline semiconductors, the shallow point defects in absorber could cause unintentional doping at room temperature. The performance of PSC can be enhanced by introducing appropriate doping in absorber layer [58]. The self-doping process can be adopted for n- or p-type doping in absorber layer. Experimental studies show that n-type or p-type selfdoping in $\mathrm{CH}_{3} \mathrm{NH}_{3} \mathrm{PbI}_{3}$ lead towards the manipulation of carrier density, majority carrier type and charge transport by changing the thermal annealing or precursor ratios in the solutions [58, 59]. Formation of $\mathrm{CH}_{3} \mathrm{NH}_{3} \mathrm{PbI}_{3}$ involves organic and inorganic precursors named methyl ammonium iodide (MAI) and lead iodide $\left(\mathrm{PbI}_{2}\right)$. The ratio between precursors
( $\left.\mathrm{PbI}_{2} / \mathrm{MAI}\right)$ decides the doping of the absorber. Upon thermal annealing, $\mathrm{PbI}_{2}$ rich absorber layer is n-doped and $\mathrm{PbI}_{2}$ deficit absorber layer is p-doped [60]. Furthermore, $\mathrm{CH}_{3} \mathrm{NH}_{3} \mathrm{PbI}_{3}$ is unstable in air and humidity.

When moist air comes in contact with device then $\mathrm{PbI}_{2}$ is generated and oxidation state of lead is changed. This process is the cause of introducing impurities in absorber layer. The effect of doping concentration on the performance of perovskite solar cell is studied by choosing the values of $N_{\mathrm{A}}$ in the range of $10^{14}-10^{17} \mathrm{~cm}^{-3}$. Figure 3(a) gives the PCE of PSC with various values of doping concentration. It is worth noting that PCE is maximum when the value of $N_{\mathrm{A}}$ is $5 \times 10^{16} \mathrm{~cm}^{-3} . J_{\mathrm{sc}}$ and $V_{\mathrm{oc}}$ also have the same behaviour. It indicates that $\mathrm{QE}$ is maximum at $5 \times 10^{16} \mathrm{~cm}^{-3}$. QE increases when value of $N_{\mathrm{A}}$ ranging from $10^{14}$ to $10^{16} \mathrm{~cm}^{-3}$ as shown in figure 3(b). The results above demonstrate that charge carriers are transported and collected more efficiently at the same irradiance when $N_{\mathrm{A}}$ of the absorber is $5 \times 10^{16} \mathrm{~cm}^{-3}$. Therefore, proper selection of $N_{\mathrm{A}}$ is critical for the improvement of performance of PSCs. On the other hand, $J_{\mathrm{sc}}$ decreases when values of $N_{\mathrm{A}}$ increases beyond $5 \times 10^{16} \mathrm{~cm}^{-3}$. The variation in the cell performance with the doping concentration can be explained in terms of built-in electric field which is enhanced with the increase of doping concentration. The charge carriers are separated and increased by the increase of electric field resulting in the enhanced performance of PSCs [61].

The decrease in $J_{\mathrm{sc}}$ with increasing doping concentration could be explained from the perspective of Auger recombination. Auger recombination rate increases with further increase of doping density beyond $5 \times 10^{16} \mathrm{~cm}^{-3}$. It is also clear that total recombination rate also increases when doping density increases beyond $5 \times 10^{16} \mathrm{~cm}^{-3}$ as shown in figure 3(c). The scattering and recombination increases due to increasing doping density thus suppressing hole transportation [62]. Therefore, optimum doping density enhances the $V_{\mathrm{oc}}$ and $J_{\mathrm{sc}}$ which in turn increases the PCE. While further 

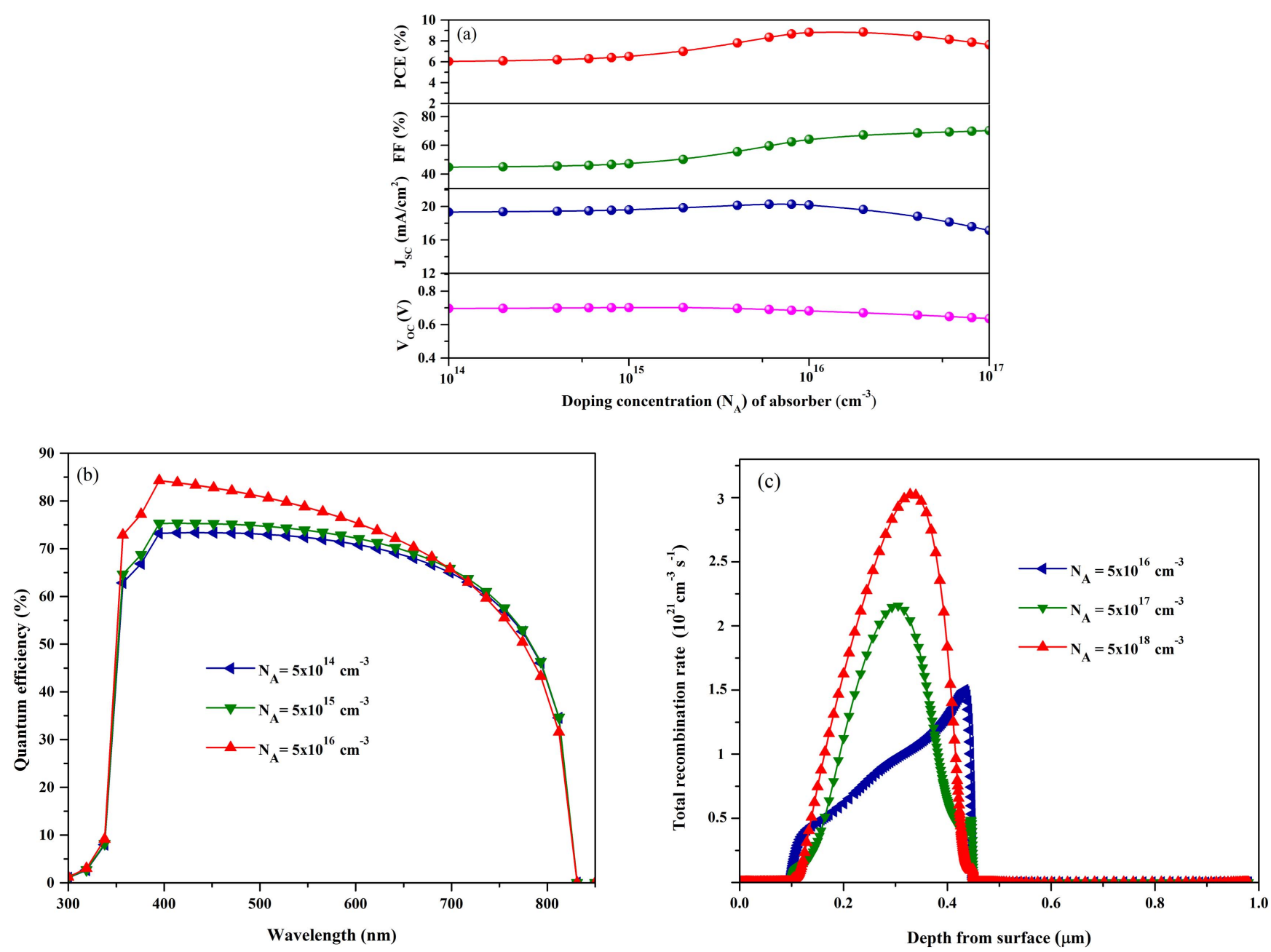

Figure 3. Variation in (a) performance parameters (b) quantum efficiency of PSC and (c) total recombination rate with different $N_{\mathrm{A}}$ values of absorber layer.

increase in doping density is not favourable due to high recombination and scattering. There should be lower carrier concentration in lead perovskite so that carrier mobility can increase within the absorber. The optimum performance with $J_{\mathrm{sc}}$ of $18.47 \mathrm{~mA} \mathrm{~cm}^{-2}, V_{\mathrm{oc}}$ of $0.65 \mathrm{~V}, \mathrm{FF}$ of $68.97 \%$ and PCE of $8.31 \%$ is obtained under the doping density of $5 \times 10^{16} \mathrm{~cm}^{-3}$. The comparison is shown between $J-V$ curves with and without optimizing of $N_{\mathrm{A}}$ in curve (c) of figure 2(a). With the optimization, PCE increases $1.47 \%$ as compared with the device having initial value of $N_{\mathrm{A}}=2.1 \times 10^{17} \mathrm{~cm}^{-3}$.

\subsection{Influence of electron affinity of ETM and HTM}

The critical factor between $\mathrm{TiO}_{2} /$ perovskite/CuI is band offset which determines the carrier recombination at the interface and is the measure of $V_{\mathrm{oc}}$. By varying the values of electron affinities of $\mathrm{TiO}_{2}(3.7-4.6 \mathrm{eV})$ and $\mathrm{CuI}(2.0-3.0 \mathrm{eV})$, the band offset can be adjusted. Figures 4 and 5(a) show variation of PCE, $V_{\mathrm{oc}}, J_{\mathrm{sc}}$ and FF with electron affinity of ETM and HTM respectively. The values of $2.2-2.6 \mathrm{eV}$ and 3.9-4.0 eV give the better $\mathrm{PCE}$ for $\mathrm{CuI}$ and $\mathrm{TiO}_{2}$ respectively. When the electron affinity of HTM is too low (lower than

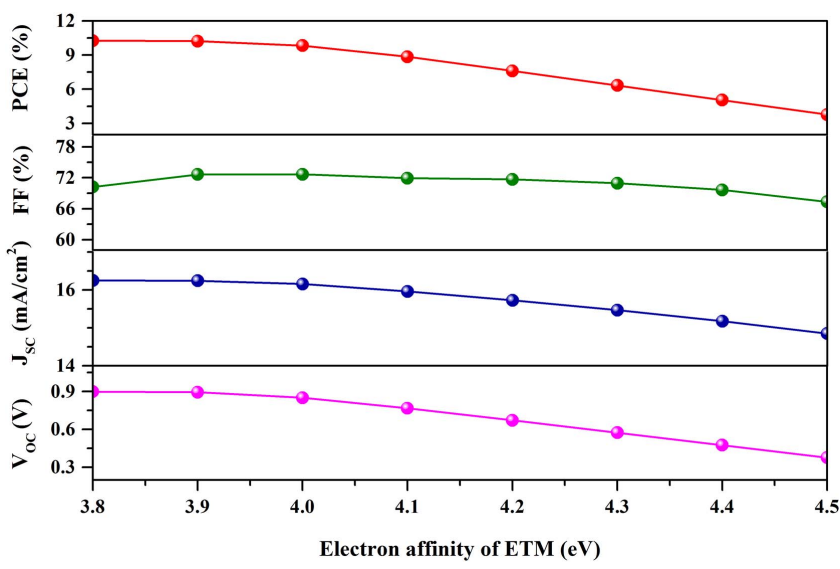

Figure 4. Variation in performance parameters of PSC with electron affinity of ETM.

$2.1 \mathrm{eV}$ ), then $V_{\text {oc }}$ decreases slightly. When the electron affinity of HTM is too high (higher than $2.6 \mathrm{eV}$ ), then $J_{\mathrm{sc}}$ decreases appreciably.

PCE of $10.28 \%, J_{\mathrm{sc}}$ of $16.35 \mathrm{~mA} \mathrm{~cm}^{-2}, V_{\mathrm{oc}}$ of $0.90 \mathrm{~V}$ and FF of $69.85 \%$ are obtained upon optimizing values of electron affinity of ETM $(3.85 \mathrm{eV})$ and HTM $(2.57 \mathrm{eV})$. The optimized 
Table 4. Variation in diffusion length with different values of defect density in absorber layer.

\begin{tabular}{llllllll}
\hline Defect density $\left(\mathrm{cm}^{-3}\right)$ & $1 \times 10^{14}$ & $1 \times 10^{15}$ & $1 \times 10^{16}$ & $1 \times 10^{17}$ & $1 \times 10^{18}$ & $1 \times 10^{19}$ & $1 \times 10^{20}$ \\
\hline Diffusion length $(\mu \mathrm{m})$ & 508 & 160 & 50 & 16 & 5 & 1.6 & 0.5 \\
\hline
\end{tabular}

$J-V$ curve with improved band offset values is shown in curve (b) of figure 2(a). It is evident that proper ETM and HTM selection with suitable electron affinity can reduce the recombination of carriers and performance of PSCs can further be optimised [63].

\subsection{Influence of hole mobility and doping concentration $\left(N_{A}\right)$ of HTM}

Hole mobility is a measure of holes transport under the action of electric field. Hole mobility is affected by doping level and doping concentration of acceptor. Lattice scattering and ionized impurity scattering limit the hole mobility in the material at low acceptor doping and high acceptor doping respectively.

The effect of hole mobility in $\mathrm{CuI}$ has been computed on performance parameters. Figure 5(b) shows the increase in $J_{\mathrm{sc}}$ and PCE with the increase in hole mobility which signifies the better charge transport and charge extraction at the HTM/absorber interface. Figure 5(c) represents the effect of $N_{\mathrm{A}}$ on the performance parameters. It indicates that PCE is low at low level of $N_{\mathrm{A}}$ which is due to high series resistance in accordance to previous studies $[64,65]$. PCE of $6.92 \%, J_{\mathrm{sc}}$ of $15.60 \mathrm{~mA} \mathrm{~cm}^{-2}, V_{\mathrm{oc}}$ of $0.613 \mathrm{~V}$ and $\mathrm{FF}$ of $72.31 \%$ are obtained upon optimizing values of hole mobility $\left(5 \times 10^{-2} \mathrm{~cm}^{2} \mathrm{~V}^{-1} \mathrm{~s}^{-1}\right)$ and doping concentration $\left(5 \times 10^{19} \mathrm{~cm}^{-3}\right)$. The optimised $J-V$ curve with improved performance is shown in curve (f) of figure 2(a).

\subsection{Influence of defect density $\left(N_{t}\right)$ and thickness of absorber layer}

By the adjustment of electron affinity of ETM and HTM as well as doping concentration of absorber, solar cell PCE can be enhanced to certain extent. For further improvement in performance of PSC, defect density is another critical parameter which should be discussed. The performance of perovskite solar cell is greatly affected by the morphology and quality of absorber layer [66]. When light is irradiated upon PSC, photoelectrons are generated in the absorber layer. Poor film quality can affect the coverage of lead perovskite on $\mathrm{TiO}_{2}$ layer $[67,68]$. If the quality of film is poor then defect density increases and recombination rate of carriers becomes dominant in absorber layer which determine the $V_{\mathrm{oc}}$ of the solar cell.

Shockley-Read-Hall (SRH) recombination model is used to determine the effect of defect density on performance of PSC [69].

$$
R^{\mathrm{SRH}}=\frac{n \cdot p-n_{i}^{2}}{\tau_{p} \cdot\left(n+n_{1}\right)+\tau_{n} \cdot\left(p+p_{1}\right)},
$$

where $n_{1}$ and $p_{1}$ are concentrations of electrons and holes in trap defects and in valence band respectively

$$
\begin{aligned}
& n_{1}=N_{\mathrm{c}} \cdot \exp \left(\frac{-\left(E_{\mathrm{c}}-E_{\mathrm{T}}\right)}{k_{\mathrm{B}} \cdot T_{\mathrm{L}}}\right), \\
& p_{1}=N_{\mathrm{v}} \cdot \exp \left(\frac{-\left(E_{\mathrm{T}}-E_{\mathrm{v}}\right)}{k_{\mathrm{B}} \cdot \mathrm{T}_{\mathrm{L}}}\right),
\end{aligned}
$$

$n$ and $p$ are the concentrations of electrons and holes at equlibrium and $T_{\mathrm{L}}$ is lattice temperature while $n_{i}$ is the intrinsic carrier concenntration

$$
n_{\mathrm{i}}^{2}=n p=n_{1} p_{1}=N_{\mathrm{c}} N_{\mathrm{v}} \exp \left(\frac{-E_{\mathrm{g}}}{k_{\mathrm{B}} \cdot T_{\mathrm{L}}}\right) .
$$

At the condition $E_{g}(\mathrm{eV}) \gg 3 k_{\mathrm{B}} T_{\mathrm{L}}, n_{\mathrm{i}}^{2}$ can be neglected which are generated thermally. $E_{\mathrm{T}}$ is the energy level of trap defect and $N_{\mathrm{t}}$ is the density of trap defect. Carrier life time is represented by $\tau_{n, p}$

$$
\tau_{n, p}=\frac{1}{\sigma_{n, p} \cdot v_{\text {th }} \cdot N_{\mathrm{t}}} .
$$

$\sigma_{n, p}$ is capture cross-section of the electrons and holes and $v_{\text {th }}=10^{+7} \mathrm{~cm} \mathrm{~s}^{-1}$ is the thermal velocity.

Diffusion coefficient $(D)$ is given by

$$
D=\frac{\mu k_{\mathrm{B}} T}{q} \text {. }
$$

$\mu$ is the carrier mobility, $k_{\mathrm{B}}$ is Boltzmann constant, $T$ is temperature in kelvin and $q$ is magnitude of charge.

Diffusion length $(L)$ is given by

$$
L=\sqrt{D \tau} .
$$

By equations (5)-(7), diffusion lengths of the electrons $\left(L_{n}\right)$ and holes $\left(L_{p}\right)$ have been calculated. The simulated values of diffusion length of electrons and holes are the same as all parameters like capture cross section, thermal velocity and mobility for electrons and holes in the absorber layer is set to be same. In reality, holes have slightly small diffusion length because of large effective mass. Larger diffusion lengths corresponds to the better performance in perovskite as well as bulk heterojunction solar cells $[70,71]$. There is very small effect on the validity of simulation by ignoring the difference of diffusion lengths between electrons and holes.

The initial value of $N_{\mathrm{t}}$ in the absorber is set to be $4.5 \times 10^{17} \mathrm{~cm}^{-3}$. Based on previous simulated studies [36, 72], the range of defect density is considered to be $10^{14}-10^{19} \mathrm{~cm}^{-3}$. The $J-V$ curves with the defect density range are shown in figure 6(a). The performance of the PSC decreases with the increase of defect density in the absorber as shown in figure 6(b). When $N_{\mathrm{t}}$ in the absorber is increased from $10^{14}$ to $10^{15} \mathrm{~cm}^{-3}$, there is a slight degradation in the cell performance. It is difficult to achieve such a low value of defect density as low as $10^{14} \mathrm{~cm}^{-3}$ in experimental work. 

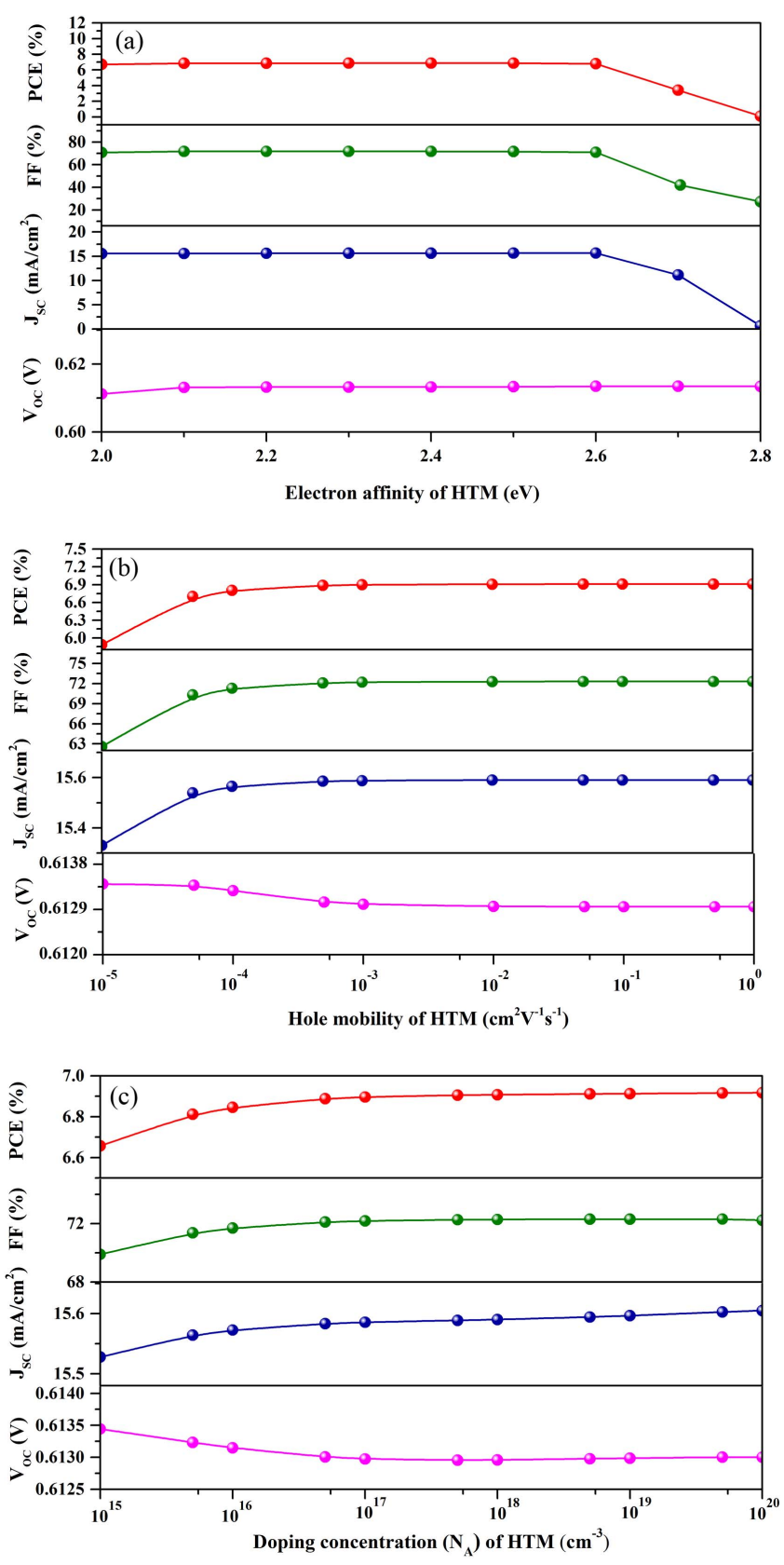

Figure 5. Variation in performance parameters of PSC with (a) electron affinity of HTM (b) increasing hole mobility of HTM, and (c) increasing doping concentration of HTM.

Therefore, we chose $1 \times 10^{15} \mathrm{~cm}^{-3}$ as optimized value of $N_{\mathrm{t}}$. The device performance is optimized as $J_{\mathrm{sc}}$ of $18.72 \mathrm{~mA} \mathrm{~cm}^{-2}, V_{\text {oc }}$ of $0.62 \mathrm{~V}, \mathrm{FF}$ of $77.31 \%$ and PCE of $8.99 \%$. Carrier diffusion length is considered to analyse the effect of defect density on the performance of device depending on SRH effect and diffusion length formula. It is clear from table 4 that the lower the defect density, the large is the diffusion length which leads towards the better performance of the cell. There is another parameter, thickness of absorber layer, which affects the performance of solar cell. The influence of thickness of absorber on the performance parameters is shown in the figure 7(a). PCE is lower when
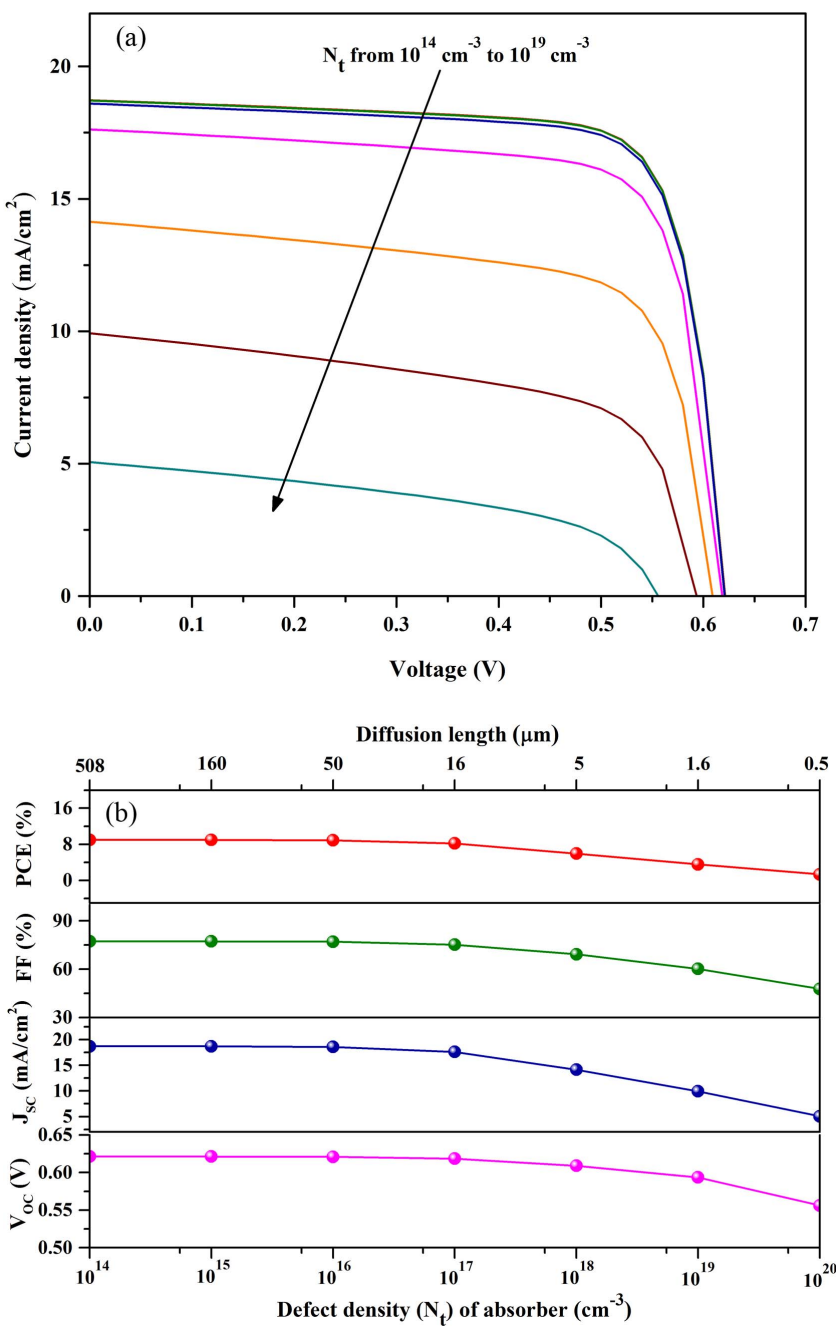

Figure 6. (a) $J-V$ curves and (b) variation in performance parameters of PSC with different values of defect density $N_{\mathrm{t}}$.

thickness of the layer is too small due to the poor light absorption. PCE of PSCs increases with the increase of the thickness of the absorber before reaches a constant value at $600 \mathrm{~nm}$. For absorber thicker than $600 \mathrm{~nm}$, the collection of photo generated carriers decreased because of charge recombination. Figure 7(b) indicates that $\mathrm{QE}$ increases with the increase of absorber thickness up to $300 \mathrm{~nm}$ thickness. After $300 \mathrm{~nm}$ thickness, no significant increase in QE is observed. Carrier diffusion length is the crucial factor in designing perovskite solar cell structure [73, 74]. The effect of diffusion length on PCE taking into account the thickness of absorber layer is shown in the Fig. 7(c).

The PCE of the device increases when thickness of the absorber layer increases. PCE slows down when thickness is larger than $600 \mathrm{~nm}$. Considering the effect of $\mathrm{Nt}$ and thickness of the absorber, the optimized parameters are PCE of $10.80 \%$. Jsc of $21.92 \mathrm{~mA} / \mathrm{cm}^{2}$, Voc of $0.63 \mathrm{~V}$, and FF of $78.65 \%$. The $\mathrm{J}-\mathrm{V}$ curve is shown in curve (d) of figure 2(a). The performance is improved with the fact that lower defect density leads to the larger diffusion length and lower recombination rates at the interfaces [71, 75]. It is evident from literature that pin hole free structure of methyl ammonium lead iodide 

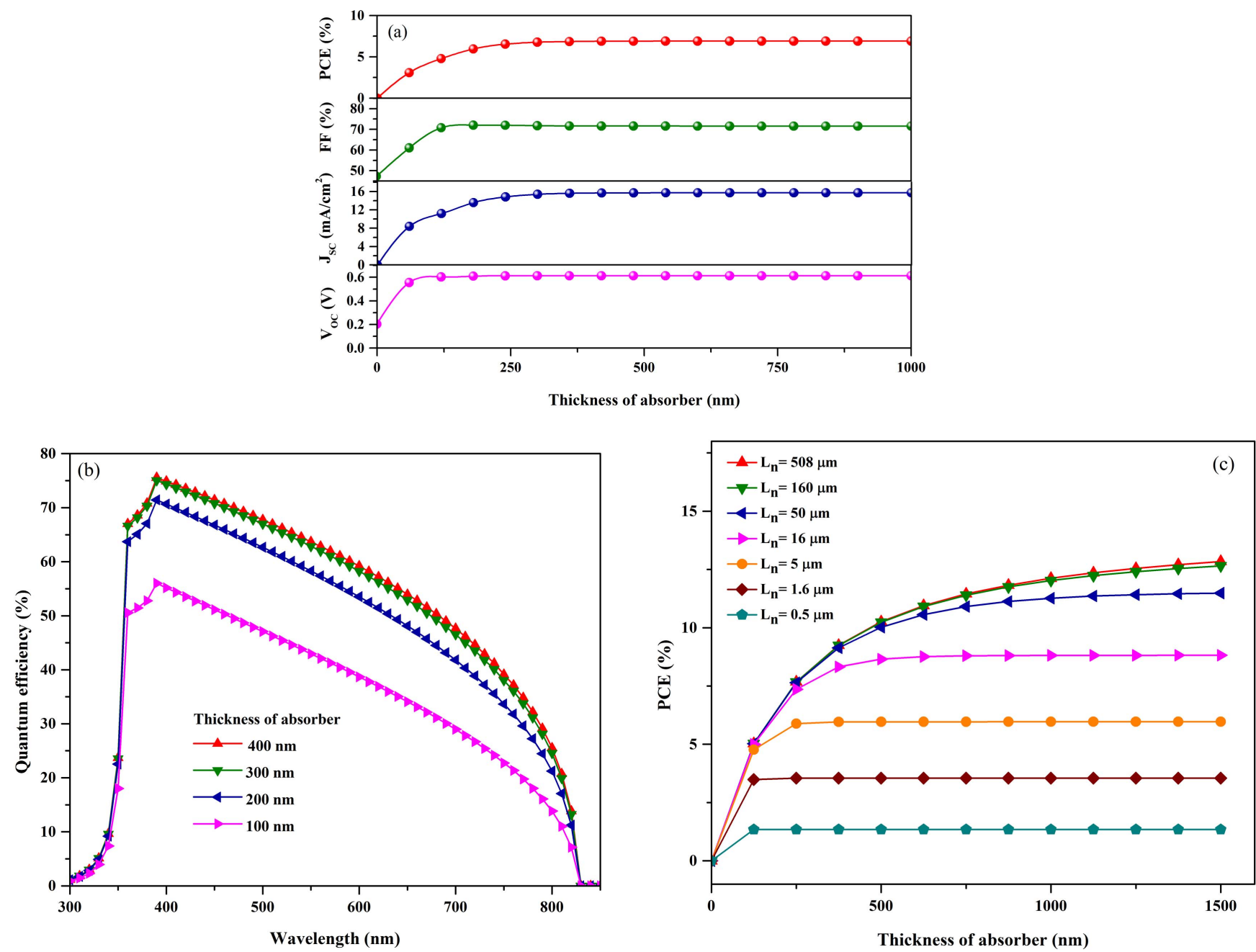

Figure 7. Variation in (a) performance parameters and (b) quantum efficiency of PSC with different thickness of absorber layer (c) variation in PCE with various diffusion lengths and thickness of absorber layer.

Table 5. Optimized parameters of the device.

\begin{tabular}{llll}
\hline Optimized parameters & ETM $\left(\mathrm{TiO}_{2}\right)$ & Absorber $\left(\mathrm{CH}_{3} \mathrm{NH}_{3} \mathrm{PbI}_{3}\right)$ & $\mathrm{HTM}(\mathrm{CuI})$ \\
\hline Doping density $\left(\mathrm{cm}^{-3}\right)$ & - & $5 \times 10^{16}$ & $5 \times 10^{19}$ \\
Electron affinity $(\mathrm{eV})$ & 3.85 & - & 2.57 \\
Defect density $\left(\mathrm{cm}^{-3}\right)$ & - & $1 \times 10^{15}$ & - \\
Thickness $(\mathrm{nm})$ & - & 600 & - \\
Hole mobility $\left(\mathrm{cm}^{2} \mathrm{~V}^{-1} \mathrm{~s}^{-1}\right)$ & - & - & $5 \times 10^{-2}$ \\
\hline
\end{tabular}

Table 6. Photovoltaic parameters of $\mathrm{CuI}$ based perovskite solar cells reported in the experimental work in the literature and simulated results using SCAPS.

\begin{tabular}{|c|c|c|c|c|c|c|c|c|c|}
\hline \multirow[b]{2}{*}{ Parameters } & \multicolumn{6}{|c|}{ Simulation } & \multirow[b]{2}{*}{ [26] } & \multirow[b]{2}{*}[56]{} & \multirow{2}{*}{$\begin{array}{c}\text { Experiment } \\
\text { [57] }\end{array}$} \\
\hline & Initial & $\begin{array}{l}\text { Optimized } \\
N_{\mathrm{A}} \text { of } \\
\text { absorber }\end{array}$ & $\begin{array}{c}\text { Optimized } \chi \\
\text { of ETM } \\
\text { and HTM }\end{array}$ & $\begin{array}{c}\text { Optimized } N_{\mathrm{t}} \\
\text { and thickness } \\
\text { of absorber }\end{array}$ & $\begin{array}{c}\text { Optimized } \mu_{\mathrm{p}} \\
\text { and } N_{\mathrm{A}} \\
\text { of HTM }\end{array}$ & $\begin{array}{c}\text { Final } \\
\text { optimization }\end{array}$ & & & \\
\hline PCE $(\%)$ & 6.85 & 8.31 & 10.28 & 10.80 & 6.92 & 21.32 & 17.60 & 6 & 7.5 \\
\hline $\mathrm{FF}(\%)$ & 71.69 & 68.97 & 69.85 & 78.65 & 72.31 & 84.53 & 75 & 62 & 57 \\
\hline$J_{\mathrm{sc}}\left(\mathrm{mA} \mathrm{cm}{ }^{-2}\right)$ & 15.57 & 18.47 & 16.35 & 21.92 & 15.60 & 25.47 & 22.78 & 17.8 & 16.7 \\
\hline$V_{\mathrm{oc}}(\mathrm{V})$ & 0.61 & 0.65 & 0.90 & 0.63 & 0.61 & 0.99 & 1.03 & 0.55 & 0.78 \\
\hline
\end{tabular}


perovskite can be obtained by using dimethyl sulfoxide (DMSO) and using polyethylene glycol (PEG) also gives a better effects on the surface morphology [76, 77]. By using solvent retarding method (SR), optimal thick and uniform perovskite film can be deposited [78].

At the end, considering all the factors as doping density, electron affinity, defect density and thickness, we obtained encouraging results, $J_{\mathrm{sc}}$ of $25.47 \mathrm{~mA} \mathrm{~cm}^{-2}, V_{\mathrm{oc}}$ of $0.99 \mathrm{~V}, \mathrm{FF}$ of $84.53 \%$ and PCE of $21.32 \%$. The final optimized parameters and optimised $J-V$ curve are shown in table 5 and curve (e) of figure 2(a) respectively. We compared our simulated results with the experiment work published by the other researchers and the related data is summarized in table 6. In the literature, the best efficiency of $17.60 \%$ has been achieved for PSCs with CuI as HTM. $V_{\text {oc }}$ of $1.03 \mathrm{~V}$ reported in the literature is already higher than the value through our simulation, while the FF and $J_{\text {sc }}$ still need be increased to achieve $21.32 \%$ efficiency. This could be achieved by further improve the film morphology and crystalline quality of both the absorber and CuI layer. Doping of $\mathrm{CuI}$ by replacing either part of $\mathrm{Cu}$ or part of I by other element might can further modify the charge carrier concentration and mobility of HTM.

\section{Conclusion}

The lead-based $\mathrm{CH}_{3} \mathrm{NH}_{3} \mathrm{PbI}_{3}$ perovskite solar cell with $\mathrm{CuI}$ as HTM are studied by one dimensional simulation programme in this work. The results exhibit that optimum doping density in the absorber layer gives improved PCE with the fact that electric field band alignment at the interfaces are changed. While too high doping concentration leads to decrease of PCE due to higher recombination rates. To reduce the recombination rates at the interfaces, proper selection is made for the electron affinity of ETM and HTM. In the simulation, defect density in the absorber layer is the most critical factor for the high performance of solar cell. By choosing the defect density as $1 \times 10^{15} \mathrm{~cm}^{-3}$, PCE of PSCs increases from $6.85 \%$ to $10.80 \%$. With the optimised thickness of $600 \mathrm{~nm}$, absorber layer can absorb more light, therefore, PCE of the device increases although effect is small (6.85\%-6.90\%). With the optimised HTM hole mobility of $5 \times 10^{-2} \mathrm{~cm}^{2} \mathrm{~V}^{-1} \mathrm{~s}^{-1}$ and doping density of $5 \times 10^{19} \mathrm{~cm}^{-3}$, charge transport and charge extraction increase at the HTM/absorber interface, thus, PCE increases up to $6.92 \%$ and overall up to $21.32 \%$ by using all optimised parameters, which is encouraging. The results show that $\mathrm{CuI}$ as alternate $\mathrm{HTM}$ has the potential to be used with $\mathrm{CH}_{3} \mathrm{NH}_{3} \mathrm{PbI}_{3}$ and can replace the spiro-MeOTAD which is costly HTM for perovskite solar cell. By optimizing the fabrication parameters, PCE of the device can further be increased.

\section{Acknowledgments}

The authors would like to thank Professor Marc Burgelman, Department of Electronics and Information Systems,
University of Gent for the development of the SCAPS software package and allowing its use. Also, S Z Haider would like to thank Higher Education Department (HED), Government of Punjab, Pakistan for pursuing higher studies.

\section{ORCID iDs}

Hafeez Anwar (10 https://orcid.org/0000-0002-0473-850X

\section{References}

[1] Gao P et al 2014 Organohalide lead perovskites for photovoltaic applications Energy Environ. Sci. 72448

[2] Giordano F, Abate A, Correa Baena J P, Saliba M, Matsui T, Im S H, Zakeeruddin S M, Nazeeruddin M K, Hagfeldt A and Graetzel M 2016 Enhanced electronic properties in mesoporous $\mathrm{TiO}_{2}$ via lithium doping for highefficiency perovskite solar cells Nat. Commun. 710379

[3] Rajamanickam N, Kumari S, Vendra V K, Lavery B W, Spurgeon J, Druffel T and Sunkara M K 2016 Stable and durable $\mathrm{CH}_{3} \mathrm{NH}_{3} \mathrm{PbI}_{3}$ perovskite solar cells at ambient conditions Nanotechnology 27235404

[4] Lim K G, Kim H B, Jeong J, Kim H, Kim J Y and Lee T W 2014 Boosting the power conversion efficiency of perovskite solar cells using self-organized polymeric hole extraction layers with high work function Adv. Mater. 26 6461-6

[5] Wang D, Wright M, Elumalai N K and Uddin A 2016 Stability of perovskite solar cells Sol. Energy Mater. Sol. Cells 147 255-75

[6] Li W et al 2014 Montmorillonite as bifunctional buffer layer material for hybrid perovskite solar cells with protection from corrosion and retarding recombination J. Mater. Chem. A 213587

[7] Sanchez R S and Mas-Marza E 2016 Light-induced effects on Spiro-OMeTAD films and hybrid lead halide perovskite solar cells Sol. Energy Mater. Sol. Cells 158 189-94

[8] Zhao X and Park N-G 2015 Stability issues on perovskite solar cells Photonics 2 1139-51

[9] Rahmi G H, Pratiwi P, Nuryadi B W, Aimon A H, Winata T and Iskandar F 2016 Preparation of copper iodide (CuI) thin film by in situ spraying and its properties $J$. Phys.: Conf. Ser. 73912050

[10] Cai N, moon S-J, Cevey-Ha L, Moehl T, Humphry-Baker R, Wang P, Zakeeruddin S M and Grätzel M 2011 An organic $\mathrm{D}-\pi$-A dye for record efficiency solid-state sensitized heterojunction solar cells Nano Lett. 11 1452-6

[11] Ahn N, Son D-Y, Jang I-H, Kang S M, Choi M and Park N-G 2015 Highly reproducible perovskite solar cells with average efficiency of $18.3 \%$ and best efficiency of $19.7 \%$ fabricated via Lewis base adduct of lead(II) iodide J. Am. Chem. Soc. 137 8696-9

[12] Cao J, Liu Y-M, Jing X, Yin J, Li J, Xu B, Tan Y-Z and Zheng N 2015 Well-defined thiolated nanographene as holetransporting material for efficient and stable perovskite solar cells J. Am. Chem. Soc. 137 10914-7

[13] Jeng J-Y, Chiang Y-F, Lee M-H, Peng S-R, Guo T-F, Chen $\mathrm{P}$ and Wen T-C $2013 \mathrm{CH}_{3} \mathrm{NH}_{3} \mathrm{PbI}_{3}$ perovskite/ fullerene planar-heterojunction hybrid solar cells $\mathrm{Adv}$. Mater. 25 3727-32

[14] Heo J H, Han H J, Kim D, Ahn T K and Im S H 2015 Hysteresis-less inverted $\mathrm{CH}_{3} \mathrm{NH}_{3} \mathrm{PbI}_{3}$ planar perovskite hybrid solar cells with $18.1 \%$ power conversion efficiency Energy Environ. Sci. 8 1602-8 
[15] Chen W-Y, Deng L-L, Dai S-M, Wang X, Tian C-B, Zhan X-X, Xie S-Y, Huang R-B and Zheng L-S 2015 Lowcost solution-processed copper iodide as an alternative to PEDOT:PSS hole transport layer for efficient and stable inverted planar heterojunction perovskite solar cells J. Mater. Chem. A 3 19353-9

[16] Zhang Y, Hu X, Chen L, Huang Z, Fu Q, Liu Y, Zhang L and Chen Y 2016 Flexible, hole transporting layer-free and stable $\mathrm{CH}_{3} \mathrm{NH}_{3} \mathrm{PbI}_{3} / \mathrm{PC} 61 \mathrm{BM}$ planar heterojunction perovskite solar cells Org. Electron. 30 281-8

[17] Chen H, Pan X, Liu W, Cai M, Kou D, Huo Z, Fang X and Dai S 2013 Efficient panchromatic inorganic-organic heterojunction solar cells with consecutive charge transport tunnels in hole transport material Chem. Commun. 497277

[18] Habisreutinger S N, Leijtens T, Eperon G E, Stranks S D, Nicholas R J and Snaith H J 2014 Carbon nanotube/ polymer composites as a highly stable hole collection layer in perovskite solar cells Nano Lett. 14 5561-8

[19] Leijtens T, Giovenzana T, Habisreutinger S N, Tinkham J S, Noel N K, Kamino B A, Sadoughi G, Sellinger A and Snaith H J 2016 Hydrophobic organic hole transporters for improved moisture resistance in metal halide perovskite solar cells ACS Appl. Mater. Interfaces 8 5981-9

[20] Heo J H et al 2013 Efficient inorganic-organic hybrid heterojunction solar cells containing perovskite compound and polymeric hole conductors Nat. Photon. 7 486-91

[21] Yang W S, Noh J H, Jeon N J, Kim Y C, Ryu S, Seo J and Il Seok S 2015 Solar cells. High-performance photovoltaic perovskite layers fabricated through intramolecular exchange Science 348 1234-7

[22] Heo J H, Han H J, Lee M, Song M, Kim D H and Im S H 2015 Stable semi-transparent $\mathrm{CH}_{3} \mathrm{NH}_{3} \mathrm{PbI}_{3}$ planar sandwich solar cells Energy Environ. Sci. 8 2922-7

[23] Fakharuddin A, Jose R, Brown T M, Fabregat-Santiago F and Bisquert J 2014 A perspective on the production of dyesensitized solar modules Energy Environ. Sci. 7 3952-81

[24] Roesch R, Faber T, von Hauff E, Brown T M, Lira-Cantu M and Hoppe H 2015 Procedures and practices for evaluating thin-film solar cell stability $A d v$. Energy Mater. 51501407

[25] Li M H, Yum J H, moon S J and Chen P 2016 Inorganic p-type semiconductors: their applications and progress in dyesensitized solar cells and perovskite solar cells Energies 9 $1-28$

[26] Li X, Yang J, Jiang Q, Chu W, Zhang D, Zhou Z and Xin J 2017 Synergistic effect to high performance perovskite solar cells with reduced hysteresis and improved stability by introduction of Na-treated $\mathrm{TiO}_{2}$ and spraying-deposited $\mathrm{CuI}$ as transport layers ACS Appl. Mater. Interfaces (https://doi. org/10.1021/acsami.7b14926)

[27] Prasanthkumar S and Giribabu L 2016 Recent advances in perovskite-based solar cells Curr. Sci. 111 1173-81

[28] Amalina M N, Azilawati Y, Rasheid N A and Rusop M 2013 The properties of copper (I) iodide $(\mathrm{Cul})$ thin films prepared by mister atomizer at different doping concentration Proc. Eng. 56 731-6

[29] Yang C, Kneiß M, Lorenz M and Grundmann M 2016 Roomtemperature synthesized copper iodide thin film as degenerate p-type transparent conductor with a boosted figure of merit Proc. Natl Acad. Sci. 113 12929-33

[30] Zhang P, Zhou Z, Kou D and Wu S 2017 Perovskite thin film solar cells based on inorganic hole conducting materials Int. J. Photoenergy 201710

[31] Yu Z and Sun L 2015 Recent progress on hole-transporting materials for emerging organometal halide perovskite solar cells Adv. Energy Mater. 51500213

[32] Anttu N 2015 Shockley-Queisser detailed balance efficiency limit for nanowire solar cells ACS Photon. 2 446-53
[33] Sha W E I, Ren X, Chen L and Choy W C H 2015 Suppelmentary information for the efficiency limit of $\mathrm{CH}_{3} \mathrm{NH}_{3} \mathrm{PbI}_{3}$ perovskite solar cells Appl. Phys. Lett. 106 $1-14$

[34] Burgelman M, Decock K, Kheli S and Abass A 2012 Advanced electrical simulation of thin film solar cells Thin Solid Films $\mathbf{5 3 5}$ 296-301

[35] Hossain M I, Alharbi F H and Tabet N 2015 Copper oxide as inorganic hole transport material for lead halide perovskite based solar cells Sol. Energy 120 370-80

[36] Tan K, Lin P, Wang G, Liu Y, Xu Z and Lin Y 2016 Controllable design of solid-state perovskite solar cells by SCAPS device simulation Solid State Electron. 126 75-80

[37] Amalina M and Rusop M 2012 Morphological, electrical and optical properties of $\gamma$-copper (I) iodide thin films by mist atomization technique World J. Eng. 9 251-6

[38] Mandadapu U, Vedanayakam S V and Thyagarajan K 2017 Simulation and analysis of lead based perovskite solar cell using SCAPS-1D Indian J. Sci. Technol. 10 1-8

[39] Pfeifer V et al 2013 Energy band alignment between anatase and rutile $\mathrm{TiO}_{2}$ J. Phys. Chem. Lett. 4 4182-7

[40] Calió L, Kazim S, Grätzel M and Ahmad S 2016 Holetransport materials for perovskite solar cells Angew. Chem., Int. Ed. 55 14522-45

[41] Ezealigo B N, Nwanya A C, Simo A, Osuji R U, Bucher R, Maaza M and Ezema F I 2017 Optical and electrochemical capacitive properties of copper (I) iodide thin film deposited by SILAR method Arab. J. Chem. 2017 0-11

[42] Gupta S M and Tripathi M 2011 A review of $\mathrm{TiO}_{2}$ nanoparticles Chin. Sci. Bull. 56 1639-57

[43] Jeng J-Y, Chiang Y-F, Lee M-H, Peng S-R, Guo T-F, Chen $\mathrm{P}$ and Wen T-C $2013 \mathrm{CH}_{3} \mathrm{NH}_{3} \mathrm{PbI}_{3}$ Perovskite/ Fullerene Planar-Heterojunction Hybrid Solar Cells $A d v$. Mater. 25 3727-32

[44] Liu J, Zhang Y, Liu C, Peng M, Yu A, Kou J, Liu W, Zhai J and Liu J 2016 Piezo-phototronic effect enhanced UV photodetector based on $\mathrm{CuI} / \mathrm{ZnO}$ double-shell grown on flexible copper microwire Nanoscale Res. Lett. 11281

[45] Boschloo G, Edvinsson T and Hagfeldt A 2006 chapter 8dye-sensitized nanostructured $\mathrm{ZnO}$ electrodes for solar cell applications Nanostructured Materials for Solar Energy Conversion ed T Soga (Amsterdam: Elsevier) pp 227-54

[46] Homes C C 2001 Optical response of high-dielectric-constant perovskite-related oxide Science 293 673-6

[47] Madelung O 2004 I-VII compounds Semiconductors: Data Handbook (Berlin: Springer) pp 245-74

[48] Zhao T, Shi W, Xi J, Wang D and Shuai Z 2016 Intrinsic and extrinsic charge transport in $\mathrm{CH}_{3} \mathrm{NH}_{3} \mathrm{PbI}_{3}$ perovskites predicted from first-principles Sci. Rep. 7 1-8

[49] Giorgi G, Fujisawa J I, Segawa H and Yamashita K 2013 Small photocarrier effective masses featuring ambipolar transport in methylammonium lead iodide perovskite: a density functional analysis J. Phys. Chem. Lett. 4 4213-6

[50] Fonash S J 2010 Material Properties and Device Physics Basic to Photovoltaics Solar Cell Device Physics (Amsterdam: Elsevier) ch 2 pp 9-65

[51] Zhang Q, Dandeneau C S, Zhou X and Cao G 2009 ZnO nanostructures for dye-sensitized solar cells $A d v$. Mater. 21 4087-108

[52] Motta C, El-Mellouhi F and Sanvito S 2015 Charge carrier mobility in hybrid halide perovskites Sci. Rep. 512746

[53] El Jouad Z, Morsli M, Louarn G, Cattin L, Addou M and Bernède J C 2015 Improving the efficiency of subphthalocyanine based planar organic solar cells through the use of $\mathrm{MoO} 3 / \mathrm{CuI}$ double anode buffer layer Sol. Energy Mater. Sol. Cells 141 429-35

[54] Wang H, Liu Y, Li M, Huang H, Xu H M, Hong R J and Shen $\mathrm{H} 2010$ Multifunctional $\mathrm{TiO}_{2}$ nanowires-modified 
nanoparticles bilayer film for 3D dye-sensitized solar cells Optoelectron. Adv. Mater. Rapid Commun. 4 1166-9

[55] Bansal S and Aryal P 2016 Evaluation of new materials for electron and hole transport layers in perovskite-based solar cells through SCAPS-1D simulations 2016 IEEE 43rd Photovolt. Spec. Conf. pp 747-50

[56] Christian J A, Fung R C M and Kamat P V 2014 An inorganic hole conductor for organo-lead halide perovskite solar cells. Improved hole conductivity with copper iodide $J$. Am. Chem. Soc. (https://doi.org/10.1021/ja411014k)

[57] Sepalage G A, Meyer S, Pascoe A, Scully A D, Huang F, Bach U, Cheng Y B and Spiccia L 2015 Copper(I) iodide as hole-conductor in planar perovskite solar cells: probing the origin of $J-V$ hysteresis Adv. Funct. Mater. 25 5650-61

[58] Lim K-G, Ahn S, Kim H, Choi M-R, Huh D H and Lee T-W 2016 Self-doped conducting polymer as a hole-extraction layer in organic-inorganic hybrid perovskite solar cells $A d v$. Mater. Interfaces 31500678

[59] Wang Q, Shao Y, Xie H, Lyu L, Liu X, Gao Y and Huang J 2014 Qualifying composition dependent $p$ and $n$ self-doping in $\mathrm{CH}_{3} \mathrm{NH}_{3} \mathrm{PbI}_{3}$ Appl. Phys. Lett. 105163508

[60] Frolova L A, Dremova N N and Troshin P A 2015 The chemical origin of the p-type and n-type doping effects in the hybrid methylammonium-lead iodide $\left(\mathrm{MAPbI}_{3}\right)$ perovskite solar cells Chem. Commun. 51 14917-20

[61] Jiang C-S et al 2015 Carrier separation and transport in perovskite solar cells studied by nanometre-scale profiling of electrical potential Nat. Commun. 68397

[62] Thakur U, Kisslinger R and Shankar K 2017 One-dimensional electron transport layers for perovskite solar cells Nanomaterials 7 1-27

[63] Lim K-G, Ahn S, Kim Y-H, Qi Y and Lee T-W 2016 Universal energy level tailoring of self-organized hole extraction layers in organic solar cells and organic-inorganic hybrid perovskite solar cells Energy Environ. Sci. 9 932-9

[64] Nguyen W H, Bailie C D, Unger E L and McGehee M D 2014 Enhancing the hole-conductivity of spiro-OMeTAD without oxygen or lithium salts by using spiro(TFSI $)_{2}$ in perovskite and dye-sensitized solar cells J. Am. Chem. Soc. 136 10996-1001

[65] Toshniwal A, Jariwala A, Kheraj V, Opanasyuk A S and Panchal C J 2017 Numerical simulation of tin based perovskite solar cell: effects of absorber parameters and hole transport materials J. Nano-Electron. Phys. 9 1-4

[66] Kim H, Lim K-G and Lee T-W 2016 Planar heterojunction organometal halide perovskite solar cells: roles of interfacial layers Energy Environ. Sci. 9 12-30
[67] Ahmadian-Yazdi M R, Zabihi F, Habibi M and Eslamian M 2016 Effects of process parameters on the characteristics of mixed-halide perovskite solar cells fabricated by one-step and two-step sequential coating Nanoscale Res. Lett. 11408

[68] Barbé J et al 2017 Amorphous tin oxide as a low-temperatureprocessed electron-transport layer for organic and hybrid perovskite solar cells ACS Appl. Mater. Interfaces 9 $11828-36$

[69] Goudon T and Miljanovic A C S V 2007 On the ShockleyRead-Hall model: generation-recombination in semiconductors SIAM J. Appl. Math. 67 1183-201

[70] Johnston M B and Herz L M 2016 Hybrid perovskites for photovoltaics: charge-carrier recombination, diffusion, and radiative efficiencies Acc. Chem. Res. 49 146-54

[71] Zhou Y and Long G 2017 Low density of conduction and valence band states contribute to the high open-circuit voltage in perovskite solar cells J. Phys. Chem. C 121 1455-62

[72] Du H, Wang W, Zhu J, Moreover C and Pscs S 2016 Device simulation of lead-free $\mathrm{CH}_{3} \mathrm{NH}_{3} \mathrm{SnI}_{3}$ perovskite solar cells with high efficienc Chin. Phys. B 25 1-8

[73] Tavakoli M M, Gu L, Gao Y, Reckmeier C, He J, Rogach A L, Yao Y and Fan Z 2015 Fabrication of efficient planar perovskite solar cells using a one-step chemical vapor deposition method Sci. Rep. 514083

[74] Paraecattil A A, De Jonghe-Risse J, Pranculis V, Teuscher J and Moser J-E 2016 Dynamics of photocarrier separation in $\mathrm{MAPbI}_{3}$ perovskite multigrain films under a quasistatic electric field J. Phys. Chem. C 120 19595-602

[75] Ng A, Ren Z, Shen Q, Cheung S H, Gokkaya H C, So S K, Djurišić A B, Wan Y, Wu X and Surya C 2016 Crystal engineering for low defect density and high efficiency hybrid chemical vapor deposition grown perovskite solar cells ACS Appl. Mater. Interfaces 8 32805-14

[76] Jeon N J, Noh J H, Kim Y C, Yang W S, Ryu S and Il Seok S 2014 Solvent engineering for high-performance inorganicorganic hybrid perovskite solar cells Nat. Mater. 13 897-903

[77] Ahmed M I, Habib A and Javaid S S 2015 Perovskite solar cells: potentials, challenges, and opportunities Int. J. Photoenergy 2015 1-13

[78] Yuan Z, Yang Y, Wu Z, Bai S, Xu W, Song T, Gao X, Gao F and Sun B 2016 Approximately $800 \mathrm{~nm}$ thick pinhole-free perovskite films via facile solvent retarding process for efficient planar solar cells ACS Appl. Mater. Interfaces 8 34446-54 